\title{
Study of the Influence of Stevia and Fructose to the Physicochemical Characteristics of Mocaf-pedada Biscuits
}

\author{
Jariyah $^{1 *}$, Sri Winarti ${ }^{1}$, Ulya Sarofa ${ }^{1}$, Maya Regina Subagio ${ }^{1}$ \\ ${ }^{1}$ Department of Food Technology, Faculty of Engineering, University of Pembangunan Nasional “Veteran” Jawa \\ Timur, Surabaya, 60294, Indonesia \\ *Corresponding authors : jariyah.tp@upnjatim.ac.id
}

\begin{abstract}
Stevia was known to have potential as a sugar substitute sweetener that can be used in various processed foods, including biscuits. The problem in making biscuits was the use of granulated sugar which can increase human blood glucose and was dangerous for people with diabetes mellitus, so we needed a sugar substitute that was safe for diabetics, like a stevia, and fructose syrup. The purpose of this study was to determine the effect of stevia leaf powder and fructose syrup on the physicochemical and sensory properties of biscuits products based on mocaf and pedada flour. The experiment was conducted using a completely randomized design with two factors such as stevia leaf powder $(1.5 \%, 2 \%$, and $2.5 \%)$ and fructose syrup $(10 \%, 15 \%$ and $20 \%)$. The best results were obtained that biscuits with $1.5 \%$ stevia leaf powder and of $10 \%$ fructose syrup which characteristics: $81.55 \%$ of yield, $3.32 \%$ of moisture, $2.13 \%$ of ash, $9.94 \%$ of fat, $10.28 \%$ of protein, $74.33 \%$ of carbohydrates, and organoleptic of taste 3.08 (slightly like), color 3.80 (like), aroma 3.68 (like), and texture 4.56 (like very much).
\end{abstract}

Keywords: Biscuits, Mocaf flour, Pedada flour, Stevia, Fructose syrup.

\section{INTRODUCTION}

Biscuits are dry bakery products made by baking dough made of wheat flour with or without its substitution, oil/fat, with or without the addition of other food ingredients and permitted food additives (BSN 2011). So far, wheat flour has been the main ingredient, with the development of processed product innovations, this flour can be replaced by other ingredients from local commodities. One example is using mocaf flour derived from fermented cassava, and pedada flour from a type of mangrove fruit. Pedada (Sonneratia caseolaris) one of fruit mangrove variety, which is green, has a sour taste and a distinctive aroma, it is rich in minerals and dietary fiber that can be utilized as a food source

Biscuit products from the two types of flour produced a glycemic index value of 40.92-48.27[1]. The glycemic index (GI) of biscuit products produced is influenced by the ingredients used in making biscuits. One of the ingredients that affect the GI of biscuits is the sweetener used. The sweetener that is often used in the manufacture of biscuits is sucrose, which will have an impact on increasing the GI value of the biscuits. [2] [12].

Estuti and Kunaepah [3], state that calories of sucrose is quite high $3.94 \mathrm{kcal} / \mathrm{g}$. Consumption of sucrose that is too high can cause high sugar levels in the body so that it can trigger other degenerative diseases. Therefore, lowcalorie sweeteners are needed such as honey, stevia, sorbitol, fructose syrup, cassava sugar, and several other sweetener products .

Sugar substitutes must meet the requirements, namely, they must have a sweet taste, are not toxic, are inexpensive, cannot be fermented by dental plaque bacteria, have calories, besides that must also be industrially feasible[4]. Of all these requirements, stevia and fructose syrup meet the criteria as a substitute for sucrose sugar and glucose syrup. Stevia is a natural sugar that is widely used as a substitute for sucrose. In this study, stevia leaf powder and fructose syrup were used. Stevia leaves can stimulate insulin production to normalize blood glucose[5]. The main sweetening components contained in 
stevia leaves include stevioside and rebaudioside which are about 300 times sweeter than sucrose $(0.4 \%$ solution) and are resistant to processing temperatures[6]. Fructose syrup has a sweetness level of 1.8 times that of sucrose. Fructose has a role as antidiabetic or hypoglycemic. The glycemic index of fructose is 20, sucrose is 59 and glucose is 100 [6][7].

The use of stevia leaf powder and fructose syrup as a sweetener in making biscuits is expected to reduce the GI value of biscuits. In this study, the use of stevia leaf powder and fructose syrup on the

\section{MATERIALS AND METHOD}

\subsection{Materials}

The ingredients used in making biscuits are pedada fruit obtained from the Wonorejo-Surabaya area and mocaf flour from the "Ladang Lima" brand. Other supporting ingredients such as skim milk powder, salt, margarine, egg yolk, fructose syrup, emulsion, and sodium bicarbonate. The stevia leaf powder was purchased from Surabaya. The materials used in the analysis were $\mathrm{NaOH}$, Fehling A, Fehling B, distilled water, $0.1 \mathrm{~N}$ hydrochloric acid, acetic acid, petroleum ether, iodine, filter paper, wool yarn, $2 \%$ boric acid, $70 \%$ alcohol, cotton.

\subsection{Preparation of Pedada Flour}

The pedada flour was processed by Jariyah et al.[8], that is the pedada fruits was stripped washed and blanched at $80^{\circ} \mathrm{C}$ for 15 minutes, then crushed, filtered, dried at $\pm 50-60^{\circ} \mathrm{C}$ with cabinet drying for $15-18 \mathrm{~h}$, and grind and sifted 80 mesh.

\subsection{Biscuit Preparation}

Biscuit samples were prepared according to the procedure described by Jariyah et al.[9]. Mocaf flour $(80 \mathrm{~g})$ and $20 \mathrm{~g}$ PFF were mixed with stevia leaf powder $(1.5 ; 2.0$ and $2.5 \% \mathrm{w} / \mathrm{w}), 20 \mathrm{~g}$ of skim, $1.0 \mathrm{~g}$ of salt, $50 \mathrm{~g}$ of margarine, $8 \mathrm{~g}$ of egg yolk, fructose syrup (10.0; 15.0; and $20.0 \% \mathrm{v} / \mathrm{w}$ ), $0.5 \mathrm{~g}$ of SSL (sodium stearoyl lactylate) and $0.5 \mathrm{~g}$ of sodium bicarbonate. After mixing, the dough was manually sheeted to a 0.3 $\mathrm{mm}$ thickness and cut in circles of $2.5 \mathrm{~cm}$ in diameter and placed on an aluminum sheet.

Six pieces were obtained from each batch. The biscuits were baked for $11 \mathrm{~min}$ at $180^{\circ} \mathrm{C}$ in a forced convection oven (Cosmos, Indonesia) equipped with a temperature controller. The six biscuit pieces were placed in the centre of the oven and baked. After baking, the biscuits were cooled down to room temperature before analysis. The baking tests and associated measurements were replicated three times for each sample. Biscuit products were analyzed by yield, moisture, protein, fat, ash, and carbohydrate by difference were determined according to Ooi et al. [10].

\subsection{Organoleptic Test}

Twenty five panelists were from both sexes, and from different ages, they were requested to taste each sample separately without comparing it with another sample. The samples were evaluated for desirability in color, crispiness, texture, and taste, using a 7-hedonic scale test as described by Kemp[11], varying from 7, which means like extremely to 1 , which means dislike extremely. Water was used to neutralize the taste between samples testing.

\subsection{Statistical Analysis}

All analyses were carried out in triplicates and they were analyzed using Analysis of Variance. Data obtained were subjected to statistical analysis (ANOVA) using Statistical Package for the Social Sciences, SPSS (version 16). Mean values were separated using Duncan's New Multiple Range (DNMR) test and a significant difference was accepted at a 5\% confidence level.

\section{RESULTS AND DISCUSSION}

\subsection{Yield, Moisture, and Ash Properties of Biscuits}

The substitution of stevia leaf powder and fructose syrup on biscuits based on mocaf and pedada flour had no significant effect on yield, moisture content and ash of the biscuits. So that the

Table 1 The yield, moisture, and ash of biscuits product

\begin{tabular}{cccc}
\hline Stevia leaf powder $(\%)$ & Yield $(\%)$ & Moisture $(\%)$ & Ash $(\%)$ \\
\hline 1.5 & $81.39 \pm 0.19^{\mathrm{a}}$ & $3,45 \pm 0.11^{\mathrm{a}}$ & $2,21 \pm 0.15^{\mathrm{a}}$ \\
2.0 & $81.35 \pm 0.15^{\mathrm{a}}$ & $3.77 \pm 0.09^{\mathrm{b}}$ & $2.38 \pm 0.11^{\mathrm{ab}}$ \\
2.5 & $81.29 \pm 0.07^{\mathrm{a}}$ & $4.12 \pm 0.12^{\mathrm{c}}$ & $2.66 \pm 0.14^{\mathrm{ab}}$ \\
\hline Fructose Syrup $(\%)$ & & & \\
\hline 10.0 & $81.45 \pm 0.04^{\mathrm{a}}$ & $3.66 \pm 0.31^{\mathrm{a}}$ & $2.32 \pm 0.26^{\mathrm{a}}$ \\
15.0 & $81.30 \pm 0.17^{\mathrm{a}}$ & $3.78 \pm 0.31^{\mathrm{b}}$ & $2.41 \pm 0.20^{\mathrm{a}}$ \\
20.0 & $81.28 \pm 0.05^{\mathrm{a}}$ & $3.90 \pm 0.30^{\mathrm{c}}$ & $2.53 \pm 0.23^{\mathrm{a}}$ \\
\hline
\end{tabular}

The moisture for each treatment had a significant effect $(p \leq 0.05)$, ranging from $3.45-4.12 \%$. Table 1 shows that moisture increases with increasing stevia leaf powder because the stevia leaf powder contains stevioside which has a hydroxyl group and is polar so it easily binds to water so that the moisture increases. According to Vatankhah et al [12], the increase in stevioside in stevia leaf powder results in an increase in the moisture of the biscuits. The polar hydroxyl group in stevioside is hydrophilic which easily binds to water. 
Fructose syrup has hygroscopic properties and is able to bind free water in the material. The higher the addition of fructose syrup in a food ingredient, the more free water is bound [13]. When fructose is added to food, there will be covalent bonds between the $\mathrm{O}$ and $\mathrm{H}$ groups of fructose with the $\mathrm{O}$ and $\mathrm{H}$ groups in water. So that when heating occurs in the manufacture of biscuits, the water evaporated by the biscuits with a little fructose substitution. This causes when measuring the moisture in biscuits with fructose substitution will produce more water [7].

Biscuits due to stevia powder substitution had a significant effect on ash $(\mathrm{p} \leq 0.05)$, but fructose syrup had no significant effect $(\mathrm{p} \geq 0.05)$ (Table 1$)$, ranging from $2.21-2.66 \%$. The ash increases with increasing stevia leaf powder because stevia leaf powder contains minerals such as calcium, phosphorus, iron, sodium, and potassium which contribute to increasing the ash of biscuits [14]

\subsection{Fat, protein, and carbohydrate of biscuits}

The substitution of stevia leaf powder and fructose syrup on biscuits based on mocaf flour and pedada flour had no significant effect ( $\mathrm{p} \geq 0.05)$ on fat, protein and carbohydrate content, the effect of each treatment is presented in Table 2.

Table 2 The yield, moisture, and ash of biscuits product

\begin{tabular}{cccc}
\hline Stevia leaf powder $(\%)$ & Fat $(\%)$ & Protein $(\%)$ & $\begin{array}{c}\text { carbohydrate by } \\
\text { difference }(\%)\end{array}$ \\
\hline 1.5 & $9.73 \pm 0.20^{\mathrm{a}}$ & $9.76 \pm 0.50^{\mathrm{a}}$ & $74.85 \pm 0.44^{\mathrm{c}}$ \\
2.0 & $9.90 \pm 0.27^{\mathrm{ab}}$ & $10.89 \pm 0.61^{\mathrm{b}}$ & $73.05 \pm 0.76^{\mathrm{b}}$ \\
2.5 & $10.55 \pm 0.79^{\mathrm{b}}$ & $11.43 \pm 0.44^{\mathrm{b}}$ & $71.24 \pm 0.98^{\mathrm{a}}$ \\
\hline Fructose Syrup $(\%)$ & & & \\
\hline 10.0 & $10.33 \pm 0.61^{\mathrm{a}}$ & $11.10 \pm 0.94^{\mathrm{a}}$ & $72.59 \pm 1.68^{\mathrm{a}}$ \\
15.0 & $10.11 \pm 0.53^{\mathrm{a}}$ & $10.64 \pm 0.83^{\mathrm{a}}$ & $73.06 \pm 1.77^{\mathrm{a}}$ \\
20.0 & $9.74 \pm 1.06^{\mathrm{a}}$ & $10.34 \pm 0.86^{\mathrm{a}}$ & $73.48 \pm 1.61^{\mathrm{a}}$ \\
\hline
\end{tabular}

Based on table 2 and 3, the government side is not being asked because at Balai POM Semarang their work is only to control, audit the products, and give the result to the central BPOM later on. They do not focus on the research, and downstream of the product as central BPOM did.

Biscuit fat content ranged from 9.73 to $10.55 \%$, the addition of stevia leaf powder, fat of biscuits increases, because the stevia leaf powder contains fat, so the higher the addition of stevia powder will increase the fat. According to Gasmalla et al [14] the fat content of dried stevia leaves is $4.39 \%$. The treatment of fructose syrup does not contribute to the fat of biscuits, because fructose syrup does not contain fat. Rippe [7] stated that there is no fat in fructose, so the addition of fructose does not affect the fat content of the biscuits produced.
Protein ranging from 9.76-11.43\%, stevia leaf powder had a significant effect $(\mathrm{p} \leq 0.05)$ on protein while the fructose syrup had no significant effect $(p \geq 0.05)$. The increase in stevia leaf powder added, the protein biscuits increased, because stevia leaf powder contains protein. According to Gasmalla et al [14], the protein content in dried stevia leaves is $12.44 \%$. Fructose syrup does not contribute to the results of the analysis of protein, because fructose syrup does not contain protein, so it does not affect the protein content of the biscuits produced.

Stevia leaf powder had a significant effect $(\mathrm{p} \leq 0.05)$ on carbohydrate and fructose syrup had no significant effect ( $\mathrm{p} \geq 0.05$ ) Table 2, range from $71.24-74.85 \%$. The higher added stevia leaf powder, the carbohydrate biscuits decreased, because the carbohydrates were calculated by the by difference method with the reduction of other components. In this study, the moisture, ash, fat and protein content increased so that carbohydrates decreased. According to Ooi, et al[10], carbohydrates by difference are influenced by other nutritional components, namely protein, fat, water, and ash, the higher the other nutritional components, the lower the carbohydrate content.

The addition of fructose syrup had no effect on the resulting biscuit carbohydrates, because the fructose syrup only has a small carbohydrate content of 25 grams so that it has no effect on the carbohydrate of biscuits.

\subsection{Organoleptic of Biscuit Product}

The substitution of stevia leaf powder and fructose syrup on biscuits based on mocaf flour and pedada flour had a significant effect $(\mathrm{p} \leq 0.05)$ on the panelists' preference level of taste, color, aroma, and texture (Table 3).

Table 3 The score organoleptic of taste, color, aroma, and texture of biscuits product

\begin{tabular}{cccccc}
\hline \multicolumn{2}{c}{ Treatment } & Taste & Color & Aroma & Texture \\
\cline { 1 - 4 } $\begin{array}{c}\text { Stevia leaf powder } \\
(\%)\end{array}$ & $\begin{array}{c}\text { Fructose syrup } \\
(\%)\end{array}$ & & & & \\
\hline \multirow{2}{*}{1.5} & 10.0 & 3.16 & 3.12 & 3.28 & 3.16 \\
& 15.0 & 3.08 & 3.00 & 3.32 & 3.12 \\
2.0 & 20.0 & 2.88 & 3.00 & 3.04 & 3.04 \\
\hline \multirow{2}{*}{2.5} & 10.0 & 4.04 & 3.60 & 3.24 & 3.52 \\
& 15.0 & 3.88 & 3.28 & 3.72 & 3.24 \\
& 20.0 & 3.08 & 3.28 & 3.20 & 3.16 \\
\hline & 10.0 & 2.80 & 2.96 & 3.04 & 3.20 \\
& 15.0 & 2.68 & 2.92 & 3.04 & 3.00 \\
& 20.0 & 2.40 & 2.72 & 2.84 & 2.92 \\
\hline
\end{tabular}

Table 3 shows the biscuit taste scores ranging from 2.68-4.04, increased stevia leaf powder and fructose decreased taste, because the two sweeteners had a higher sweetness level than sucrose, but there was a slightly bitter taste that decreased the biscuit taste preference. Biscuit color score ranged from 2.72-3.60, increasing stevia leaf powder and fructose decrease color preference, due to 
fructose reacting with amino acids during the baking process to produce a dark color, due to the Maillard reaction[15]. The biscuit aroma score ranged from 2.84-3.72, statistical results showed that stevia leaf powder and fructose syrup did not affect the biscuit aroma. The aroma of biscuits comes from supporting ingredients such as butter and eggs. The biscuit texture score ranged from

2.92-3.52, increase stevia leaf powder and fructose syrup made the biscuit texture not crunchy, because there were hygroscopic and had the ability to bind water, so water was free to be retained, which had an impact on the texture biscuits.

\section{CONCLUSION}

The results showed that stevia leaf powder and fructose syrup had no significant effect on the yield, moisture, ash, protein, fat, and carbohydrates of biscuits. The best treatment was obtained by substitution of $1.5 \%$ stevia leaf powder and $10.0 \%$ fructose syrup with the characteristics of $81.55 \%$ yield, $3.32 \%$ of moisture, $2.13 \%$ of ash, $9.94 \%$ of fat, $10.28 \%$ of protein, $74.33 \%$ of carbohydrates, organoleptic taste 3.08 (slightly liked), color 3.80 (liked), aroma 3.68 (liked) and texture 4.56 (liked very much).

\section{ACKNOWLEDGMENTS}

The researcher thanked Kemenristek Dikti for providing research funds in the 2021 PTUPT scheme.

\section{REFERENCES}

[1] Jariyah, N. Elvandari, S. Winarti, and U. Sarofa, "Glycemic Index of Biscuit NonWheat from Mangrove Fruits Flour with Arrowroot and Canna Flours," vol. 194, no. FANRes 2019, pp. 213-218, 2020, doi: 10.2991/aer.k.200325.041.

[2] E. Yildiz and D. Gocmen, "Use of almond flour and stevia in rice-based gluten-free cookie production," J. Food Sci. Technol., vol. 58, no. 3, pp. 940-951, 2021, doi: 10.1007/s13197-020-04608-x.

[3] W. Estuti and U. Kunaepah, "Formulation of guava (Psidium guajava) and purple sweet potato (Ipomoea batatas L. poir) velva with low calorie sweeter as an alternative of functional food," J. Crit. Rev., vol. 7, no. 5, pp.
197-199, 2020, doi: 10.31838/jcr.07.05.33.

[4] F. Patra, S. K. Tomar, and S. Arora, "Technological and functional applications of low-calorie sweeteners from lactic acid bacteria," J. Food Sci., vol. 74, no. 1, 2009, doi: 10.1111/j.1750-3841.2008.01005.x.

[5] P. Singh and L. Kashyap, Sugar and Sugar Derivatives: Changing Consumer Preferences, no. April 2021. 2020.

[6] G. Kroyer, "Stevioside and Stevia-sweetener in food: Application, stability and interaction with food ingredients," J. fur Verbraucherschutz und Leb., vol. 5, no. 2, pp. 225-229, 2010, doi: 10.1007/s00003-010-0557-3.

[7] J. M. Rippe, Fructose, high fructose corn syrup, sucrose, and health: Modern scientific understandings. 2014.

[8] J. Jariyah, L. Lailatul Azkiyah, S. B. Widjanarko, T. Estiasih, and S. S. Yuwono, "Hypocholesterolemic Effect of Pedada (Sonneratia caseolaris) Fruit Flour in Wistar Rats," Int. J. PharmTech Res., vol. 5, no. 4, pp. 1619-1627, 2013.

[9] Jariyah, E. Yektiningsih, U. Sarofa, and P. A. Sopade, "Effect of Partial Replacement of Wheat Flour with Various Mangrove Fruit Flours and Different Emulsifiers on Physicochemical Properties of Biscuits," Indones. J. Agric. Res., vol. 01, no. 02, pp. 152-161, 2018.

[10] D. J. Ooi, S. Iqbal, and M. Ismail, "Proximate composition, nutritional attributes and mineral composition of Peperomia pellucida L. (ketumpangan air) grown in Malaysia," Molecules, vol. 17, no. 9, pp. 11139-11145, 2012, doi: 10.3390/molecules170911139.

[11] S. E. Kemp, "Application of sensory evaluation in food research: Editorial," Int. J. Food Sci. Technol., vol. 43, no. 9, pp. 1507-1511, 2008, doi: 10.1111/j.1365-2621.2008.01780.x.

[12] M. Vatankhah, F. Garavand, A. Elhamirad, and M. 
Yaghbani, "Influence of sugar replacement by stevioside on physicochemical and sensory properties of biscuit," Qual. Assur. Saf. Crop. Foods, vol. 7, no. 3, pp. 393-400, 2015, doi: 10.3920/QAS2014.0396.

[13] X. Qi and R. F. Tester, "Fructose, galactose and glucose - In health and disease," Clin. Nutr. ESPEN, vol. 33, no. xxxx, pp. 18-28, 2019, doi: 10.1016/j.clnesp.2019.07.004.

[14] M. A. A. Gasmalla, R. Yang, I. Amadou, and
X. Hua, "Nutritional composition of Stevia rebaudiana bertoni leaf: Effect of drying method," Trop. J. Pharm. Res., vol. 13, no. 1, pp. 61-65, 2014, doi: 10.4314/tjpr.v13i1.9.

[15] Q. Zhang, J. M. Ames, R. D. Smith, J. W. Baynes, and T. O. Metz, "A Perspective on the Maillard Reaction and the Analysis of Protein Glycation by Mass Spectrometry: Probing the Pathogenesis of Chronic Disease," J. Proteome Res., vol. 8, no. 2, pp. 754-769, 2009, doi: 10.1021/pr800858h. 